\title{
Characterization of Cellulase and Xylanase from Bacillus subtilis NC1 Isolated from Environmental Soil and Determination of Its Genes
}

\author{
Chang-Su Park', Dae-Ook Kang ${ }^{2}$ and Nack-Shick Choi ${ }^{3}$ * \\ ${ }^{1}$ Department of Food Science and Technology, Catholic University of Daegu, Hayang 712-702, Korea \\ ${ }^{2}$ Department of Biochemistry and Health Science, Changwon National University, Changwon 641-773, Korea \\ ${ }^{3}$ Woori Life Science Co, Ltd, Cheonan-si, Chungnam 330-858, Korea
}

Received March 21, 2012 /Revised May 29, 2012 / Accepted May 30, 2012

\begin{abstract}
A Bacillus sp. strain producing celluase and xylanase was isolated from environmental soil with LB agar plate containing carboxymethylcellulose (CM-cellulose) and beechwood xylan stained with trypan blue as substrates, respectively. Based on the 16S rRNA gene sequence and API 50 CHL test, the strain was identified as B. subtilis and named B. subtilis NC1. The cellulase and xylanase from B. subtilis NC1 exhibited the highest activities for CM-cellulose and beechwood xylan as substrate, respectively, and both enzymes showed the maximum activity at $\mathrm{pH} 5.0$ and $50^{\circ} \mathrm{C}$. We cloned and sequenced the genes for cellulase and xylanase from genomic DNA of the B. subtilis NC1 by the shot-gun cloning method. The cloned cellulase and xylanase genes consisted of a 1,500 bp open reading frame (ORF) encoding a 499 amino acid protein with a calculated molecular mass of 55,251 Da and a 1,269 bp ORF encoding a 422 amino acid protein with a calculated molecular mass of 47,423 $\mathrm{Da}$, respectively. The deduced amino acid sequences from the genes of cellulase and xylanase showed high identity with glycosyl hydrolases family (GH) 5 and 30, respectively.
\end{abstract}

Key words : Bacillus subtilis, screening, cellulase, xylanase, characterization, cloning

\section{서 론}

Cellulose와 xylan은 지구상에 풍부하게 존재하는 biomass 자원으로서 이들 biomass 자원을 산업적으로 유용한 물질로 전환하기 위한 연구가 지속적으로 수행되어져 왔다 $[10,14,20,23,25]$. 최근에는 cellulose와 xylan으로부터 기능성 올리고당과 같은 기능성 물질의 생산 뿐만 아니라 차세대 대 체 에너지로서 많은 각광을 받고 있는 바이오 에탄올을 생산 하기 위한 원료로서 cellulose와 xylan을 활용하기 위한 연구 가 높은 관심속에서 수행되어지고 있다 $[4,17,19,22,27]$. 이러한 관점에서 cellulose와 xylan의 유용한 활용을 위해서는 먼저 이들 biomass 자원의 구성 단당인 glucose와 xylose로의 분해 가 선행되어야 하는데 지구 환경오염의 문제가 현대 사회에 심각하게 대두되면서 화학적인 분해 방법을 대신하여 환경적 으로 온화한 미생물 유래의 효소를 이용하여 cellulose와 xylan을 분해하는 생물학적 방법이 많은 주목을 받게 되었다 [6,7,9,12]. Cellulose는 식물세포벽의 주성분으로서 d-glucose 가 $\beta-1,4$ 결합으로 연결되어 있는 d-glucose 중합체로서 endo$\beta-1,4$ - cellulase (EC 3.2.1.4), exo- $\beta-1,4$-cellulase (EC 3.2.1.91) 그리고 $\beta-1,4-$ glucosidase (EC 3.2.1.21)의 협동적인 상승작용 에 의하여 구성 단당인 d-glucose로 분해가 이루어진다

*Corresponding author

Tel : +82-41-589-0390-1, Fax : +82-41-589-0392

E-mail : choi8850@naver.com
[1,5,15]. 그리고, xylan은 식물 세포벽 성분 중에서 cellulose 다음으로 풍부하게 존재하는 hemicellulose의 주성분으로서 $\mathrm{d}$-xylose가 $\beta-1,4$ 결합으로 연결되어 있는 중합체이며 endo- $\beta$ -1,4-xylanase (EC 3.2.1.8)와 $\beta-1,4$-xylosidase (EC 3.2.1.37)의 상호 작용에 의해 구성 단당인 d-xylose로 분해가 이루어진다 $[3,24,26]$. 이러한 관점에서, cellulose 및 xylan의 유용한 활용 을 위해서는 이들 중합체를 분해하는 미생물 유래 효소 자원 의 발굴은 무엇보다도 중요한 연구 중의 하나라고 할 수 있으 며, 향후, 효소 자원의 산업적 활용을 위하여 효소 대량 생산 및 효소의 개량을 위한 효소 유전자의 확보 또한 효소 자원의 발굴과 함께 반드시 병행 되어야 할 중요한 연구 분야라고 할 수 있다. 본 연구에서는 다양한 토양 시료로부터 cellulase 와 xylanase 활성을 보유한 미생물을 용이하게 단리하기 위하 여 기존의 Congo-Red 시약을 이용하여 효소 생산 균주를 선 별하던 방법을 개선하여 trypan blue로 염색한 carboxymethylcellulose (CM-cellulose)와 Beechwood xylan 을 기질로 함유한 고체 배지상에서 균의 생육과 동시에 균체 로부터 분비된 효소의 활성에 의해 염색된 기질의 분해로 인 해 형성된 활성환을 확인함으로서 cellulase와 xylanase를 생 산하는 균주를 배양 배지상에서 용이하게 판별하는 방법을 활 용하여 cellulase와 xylanase를 생산하는 균주를 단리하였다. 단리한 균주는 $16 \mathrm{~S} \mathrm{rRNA}$ 유전자 분석 및 $\mathrm{API} 50 \mathrm{CHL}$ 분석을 통하여 균주 동정을 실행하였으며, 본 균주 유래의 cellulase와 xylanase의 활성에 대한 조건 및 기질 특이성을 검토하였다. 그리고, 균주 유래 효소 유전자를 cloning 한 후 효소 유전자의 
배열을 규명하였다.

\section{재료 및 방법}

\section{토양미생물의 분리 동정 및 배양}

전국의 다양한 장소에서 채취한 토양 시료 $1 \mathrm{~g}$ 을 멸균수를 이용하여 $10^{-3}-10^{-4}$ 로 희석한 후 적당량을 $1.5 \%$ agar를 함유한 Luria-Burtani (LB) (Difco, Sparks, MD, U.S.A.) 배지 성분에 기질로서 $1 \%$ 의 CM-cellulose와 Beechwood xylan을 첨가한 고체 배지에 각각 도말하여 $37^{\circ} \mathrm{C}$ 에서 2 일에서 3 일 동안 배양 하였다. 이때 균주 유래 효소에 의해 기질의 분해를 활성환의 형태로 확인하기 하기 위하여 trypan blue (Sigma, St. Louis, MO, U.S.A) 염색 시약을 $0.02 \%$ 농도로 고체 배지의 제작시에 첨가하여 기질의 염색에 이용하였다. Trypan Blue 염색시료에 의해 염색된 기질이 미생물 유래 효소에 의해 분해되어 명확 한 활성환을 생성하는 미생물을 선발하여 agar와 trypan blue 를 제외한 기질 함유 $\mathrm{LB}$ 배지에 접종하고 $37^{\circ} \mathrm{C}$ 에서 48 시간 동안 $200 \mathrm{rpm}$ 으로 배양하였다. 그리고, 본 연구에 의해 단리된 균주는 $16 \mathrm{~S} \mathrm{rRNA}$ 유전자 분석을 통하여 동정하였으며, $16 \mathrm{~S}$ rRNA에 의한 균주 동정은 솔젠트(주(Dae-jeon, Korea)에 의뢰 하였다. 또한, API $50 \mathrm{kit}$ 를 이용하여 탄소원으로 당이나 당 유도체의 이용성을 분석함으로서 균 동정을 검토하였다.

\section{효소활성 측정}

효소 활성은 $1 \%$ CM-cellulose (Sigma, St. Louis, MO, U.S.A)와 Beechwood xylan (Sigma, St. Louis, MO, U.S.A) 을 각각 기질로 보유하고 있는 $\mathrm{LB}$ 배지에 균주를 접종하여 $37^{\circ} \mathrm{C}$ 에서 $200 \mathrm{rpm}$ 으로 48 시간 동안 진탕 배양 후 원심분 리 $(8,000 \mathrm{rpm}, 15 \mathrm{~min})$ 에 의해 회수한 배양 상층액을 각각 cellulase와 xylanase 효소 활성을 측정하기 위한 효소액으 로 사용하였다. 그리고, $1 \%$ CM-cellulose와 $1 \%$ Beechwood xylan을 $50 \mathrm{mM}$ acetic acid 완충용액( $\mathrm{pH}$ 5.0)에서 용해한 용액을 cellulase와 xylanase 효소 활성 측정을 위한 각각의 기질로 사용하였다. 효소와 기질의 반응은 효소액 $200 \mu 1$ 에 기질 $200 \mu 1$ 를 첨가하여 $50^{\circ} \mathrm{C}$ 에서 10 분간 반응하였으며, 반 응 후 효소 분해 활성으로 인해 생성된 환원 말단은 Miller 에 의해 소개된 3,5-dinitrosalicylic acid (DNS) 시약(Sigma, St. Louis, MO, U.S.A)을 이용하여 다음과 같이 측정하였다 [13]. 반응 시간 종료 후 효소 반응을 정지시키기 위하여 $900 \mu \mathrm{l}$ 의 DNS 시약을 첨가 후 $100^{\circ} \mathrm{C}$ 의 열탕 속에서 10 분간 처리하였다. 그리고, 처리가 끝난 시료를 상온에서 20 분간 방치 한 후 원심분리 $(10,000 \mathrm{rpm}, 10 \mathrm{~min})$ 에 의해 상층을 회 수한 후 $540 \mathrm{~nm}$ 에서 반응 상층액의 흡광도를 측정하였다. 본 연구에서 효소 활성의 1 unit은 1 분간에 $1 \mu \mathrm{mol}$ 의 d-glucose를 생산하는 효소량으로 정의하였다.

\section{$\mathrm{pH}$, 온도 및 기질특이성}

효소 활성에 미치는 $\mathrm{pH}$ 의 영향을 검토하기 위하여 완충용 액은 $50 \mathrm{mM}$ citrate 완충용액(pH 3.0-6.0), $50 \mathrm{mM}$ phosphate 완충용액(pH 6.0-8.0), 그리고, Tris- $\mathrm{HCl}$ 완충용액 $(\mathrm{pH}$ 8.0-9.0) 을 이용하였으며, 온도의 영향은 $30^{\circ} \mathrm{C}$ 에서 $70^{\circ} \mathrm{C}$ 온도 범위에 서 효소 활성의 특성을 검토하였다. 기질에 대한 효소 활성의 특성은 1\%의 Avicel, CM-cellobiose, Beechwood xylan, 그리 고 Birchwood xylan을 각각 $50 \mathrm{mM}$ acetic acid 완충용액 $(\mathrm{pH}$ 5.0)에 용해하여 기질을 제조한 후, 각 기질에 대한 효소 활성 을 검토하였으며 효소 반응은 효소 활성 부분에서 언급한 동 일한 조건으로 검토하였다.

\section{효소 유전자 cloning 및 sequencing}

효소 유전자의 cloning에 이용한 균주 염색체 $\mathrm{DNA}$ 는 다음 과 같이 추출하였다. Tryptic Soy Broth (Difco, Sparks, MD, U.S.A.) 배지 $100 \mathrm{ml}$ 에 균을 접종하여 $30^{\circ} \mathrm{C}$ 에서 $200 \mathrm{rpm}$ 으로 3 일간 배양하였다. 배양 후 원심분리 $(6,000 \times g, 15 \mathrm{~min})$ 에 의해 균체를 회수 한 후 균체의 염색체 DNA 추출 및 본 연구에서 적용한 DNA 관련 연구 방법은 Current protocols in Molecular Biology에서 소개되어 있는 방법을 사용하여 진행 하였다[16]. Cellulase와 xylanase 유전자의 단리를 위하여 활 용한 Shot-gun cloning방법은 다음과 같이 진행하였다. 먼저 추출한 균주 염색체 DNA $250-500 \mathrm{mg}$ 를 1-3 U의 활성으로 희석된 제한 효소 $\operatorname{SauBAI}$ 를 이용하여 $37^{\circ} \mathrm{C}$ 에서 30 분간 부분 적으로 분해를 한 후 $65^{\circ} \mathrm{C}$ 에서 20 분간 열처리를 함으로서 잔 존하고 있는 제한효소 활성을 실활시켰다. 제한효소를 처리한 염색체 DNA를 $0.7 \%$ agarose 겔 상에서 전기영동하여 약 2.5 $\mathrm{kb}$ 부근의 DNA 단편 부분의 겔을 선택적으로 회수한 후 $\mathrm{Gel}$ Extraction kit (QIAGEN Inc., USA)을 이용하여 DNA를 순수 하게 정제하였으며, 정제된 약 $2.5 \mathrm{~kb}$ DNA 단편들을 제한효 소 BamHI으로 처리한 후 인산기를 제거한 pHSG298 (Takara, Japan)에 ligation하여 효소 유전자 발현 벡터를 구축하였다. 구축한 발현벡터를 이용하여 Escherichia coli (E.coll) DH5a를 형질전환시킨 후 형질전환체를 CM-cellulose와 Beechwood xylan을 각각 기질로서 이용하여 trypan blue와 kanamycin $(10 \mathrm{\mu g} / \mathrm{ml})$ 을 첨가하여 제조한 Agar-LB 배지에 도말하였다. 발현벡터의 DNA 단편에 내재되어 있는 효소 유전자 유래의 재조합 효소의 영향으로 형질전환체 주위에 명확한 활성환을 나타내는 colony를 효소 유전자를 보유한 발현벡터에 의해 형 질 전환된 colony로 간주하였다. 선택된 형질 전환체는 $\mathrm{LB}$ 배 지에 접종하여 $37^{\circ} \mathrm{C}$ 에서 $200 \mathrm{rpm}$ 으로 18 시간 배양 후 원심분 리(6,000× $g, 15 \mathrm{~min})$ 에 의해 회수되었으며 Plasmid Midi kit (QIAGEN, USA)을 이용하여 재조합 plasmid를 회수한 형질 전환체로부터 추출하였다. 추출한 재조합 plasmid에 cloning 되어 있는 DNA 단편의 염기배열은 솔젠트(ᄌᄌج)(Dae-jeon, Korea)에 의뢰하여 분석하였다. 


\section{결과 및 고찰}

\section{Cellulase 및 xylanase 생산 균주의 단리}

다양한 토양 시료를 CM-cellulose와 Beechwood xylan을 기질로 이용하여 trypan blue을 첨가하여 제조한 Agar-LB배 지에 도말한 결과 cellulase 활성으로 인해 CM-cellulose를 분 해하여 고체 배지상에서 명확한 활성환을 형성한 30 균주와 xylanase 활성으로 인해 Beechwood xylan을 분해하여 명확한 활성을 나타낸 15 균주가 얻어졌다. 획득한 균주를 각각 CM-cellulose와 Beechwood xylan을 함유한 고체 배지에서 배 양을 시킨 결과 양쪽 배지에서 모두 활성환을 형성하는 5 균주 를 선별하여 $16 \mathrm{~S}$ rRNA유전자(Gene Bank Accession number, AB701293)를 동정한 결과 모두 Bacillus subtilis와 $99.5 \%$ 의 일 치성을 나타내었기에 5 종의 균주를 모두 동일한 균주로 판단 하였다. 5 종의 균주 중 1 종류를 선택하여, API $50 \mathrm{kit}$ 를 이용 하여 탄소원으로 당이나 당 유도체의 이용성을 알아본 결과, API 50 kit 제조사의 지침에 따라 후보 균주의 생화학적 특성 또한 Bacillus subtilis로 동정되어 본 후보 균주를 Bacillus subtilis NC1로 명명하였다(Table 1). 본 연구에서는 cellulase 또는 xylanase와 같은 당질 분해효소를 생산하는 균주를 환경 시료 로부터 용이하게 단리하기 위하여 plate 상에서 trypan blue를 이용하여 polysaccharide를 분해하는 효소를 생산하는 미생물 을 단리하는 방법을 활용하여 trypan blue 염색시료를 agar 배지 제작시에 첨가하였다[11]. Tryapn blue가 가지고 있는 염색능력으로부터 기질(cellulose, xylan)을 염색하는 효과가 있어 당질분해효소(cellulase, xylanase)에 의해 기질이 분해될 때 기질을 염색하고 있던 trypan blue가 분해 작용을 받은 기 질 부위에서 제거됨으로서 그 결과 균주 주위에 명확한 활성 환을 형성하는 것을 활용함으로서 agar 배지 상에서 균주 배양 과 동시에 당질 분해 효소의 생산 균주인지 아닌지를 용이하 게 확인 할 수 있었다. 기존에 당질 분해 효소(cellulase, xylanase)를 생산하는 균주의 검토에 일반적으로 활용되어 온 Congo red 시약은 균주의 당질분해효소 생산 유무를 균 배양 과 동시에 확인 할 수 없었으며 배양한 균주를 별도로 보관한 후 균을 배양했던 고체 배지에 Congo red 시약을 처리하여 활성존의 형성 유무를 판단함으로서 균주의 효소 생산 유무를 확인 할 수 있었다. 하지만, 본 연구에서 trypan blue를 이용하 여 당질분해효소 생산 균주의 screening을 진행 한 결과 당질 분해 효소를 생산하는 균주 주위에 명확한 활성환을 확인함으 로서 균주 배양과 동시에 용이하게 당질분해효소를 생산하는 균주의 선별이 가능하였기에 당질분해효소 생산균주의 screening 과정을 시간적으로 단축시키고 그 과정 또한 간략 화 할 수 있었다. 이러한 결과는 다양한 당질 polymer의 분해 에 관여하는 효소를 생산하는 균주의 screening에 trypan blue 가 폭넓게 적용 될 수 있음을 시사한다.
Table 1. Biochemical analysis of B. subtilis NC1 with API 50 kit

\begin{tabular}{|c|c|c|}
\hline Specific & $\begin{array}{l}\text { B. subtilis } \\
\text { NC001 }\end{array}$ & $\begin{array}{l}\text { Bacillus } \\
\text { subtilis }\end{array}$ \\
\hline Shape / Gram stain & $+/ \mathrm{R}$ & $+/ \mathrm{R}$ \\
\hline Spores & + & + \\
\hline Motility & + & $\mathrm{D}$ \\
\hline Growth in air & + & + \\
\hline Growth anaerobically & + & $\mathrm{D}$ \\
\hline Catalase & + & + \\
\hline Oxidase & + & $d$ \\
\hline Glucose(acid) & + & $\mathrm{D}$ \\
\hline $\mathrm{O} / \mathrm{F} /$ - & $\mathrm{O} / \mathrm{F}$ & $\mathrm{O} / \mathrm{F} /-$ \\
\hline Spore shape & $x$ & $X$ \\
\hline Spore position & $\mathrm{U}$ & $\mathrm{U}$ \\
\hline Growth at $45^{\circ} \mathrm{C}$ & + & + \\
\hline Growth at $65^{\circ} \mathrm{C}$ & - & - \\
\hline Growth at $\mathrm{pH} 5.7$ & - & + \\
\hline Growth in $7 \% \mathrm{Nacl}$ & + & + \\
\hline Utilization of citrate & + & + \\
\hline Anaerobic growth in glucose broth & + & - \\
\hline \multirow{4}{*}{$\begin{array}{l}\text { Carbohydrate, acid from : Glucose } \\
\qquad \begin{array}{l}\text { L-Arabinose } \\
\text { Mannitol } \\
\text { Xylose }\end{array}\end{array}$} & + & + \\
\hline & d & + \\
\hline & + & + \\
\hline & $\mathrm{d}$ & + \\
\hline VP (Voges-Proskauer) test & + & + \\
\hline Starch hydirlysis & + & - \\
\hline Nitrate reduction & + & + \\
\hline Indole & - & - \\
\hline Gelatin hydrolysis & + & + \\
\hline Casein hydrolysis & + & + \\
\hline Urease & $d$ & $d$ \\
\hline LV & - & - \\
\hline Lysozyme sensitivity & $\mathrm{s}$ & $\mathrm{d}$ \\
\hline
\end{tabular}

※ D: Different reaction in different species of the genus.

$\mathrm{d}$ : Different reactions in different strains.

O: oxidation. F: fermentation. w: weak reaction.

$\mathrm{U}$ : central spore. $\mathrm{X}$ : spore oval. $\mathrm{r}$ : resistant. $\mathrm{s}$ : sensitive

$\mathrm{R}$ : rod-shaped (bacillus)

\section{$\mathrm{pH}$, 온도 및 기질특이성}

Bacillus subtilis NC1을 배양하여 회수한 배양 상층액을 효 소액으로 이용하여 효소 활성에 미치는 $\mathrm{pH}$ 와 온도에 대한 영 향을 검토한 결과 두 효소 모두 $\mathrm{pH} 5.0$ 과 온도 $50^{\circ} \mathrm{C}$ 에서 가장 높은 효소 활성을 나타내었다(Fig. 1). 그리고, 효소액에 대한 기질 특이성을 Avicel, CM-cellulose, Beechwood xylan, 그리 고 Birchwood xylan을 기질로 이용하여 검토한 결과 B. subtilis $\mathrm{NC1}$ 유래 효소액은 CM-cellulose에 대하여 가장 높은 효 소 활성을 나타내었으며 다음으로 Beechwood xylan에 대하 여 높은 활성을 나타내었다(Table 2). Birchwood xylan에 대해 서도 활성이 명확하게 확인이 되었지만 Beechwood xylan에 대해서 더 높은 효소 활성이 확인되었다. 하지만, Avicel에 대 
(A)

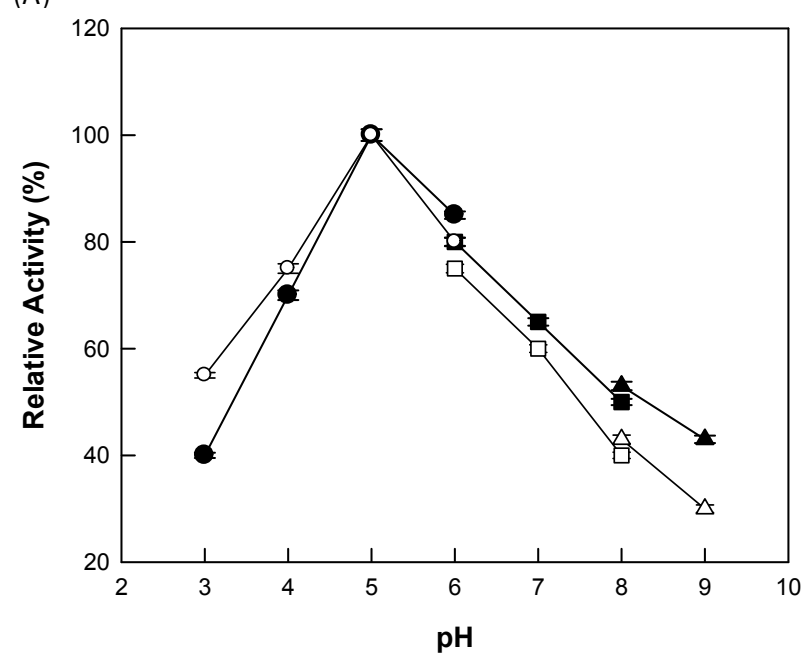

(B)

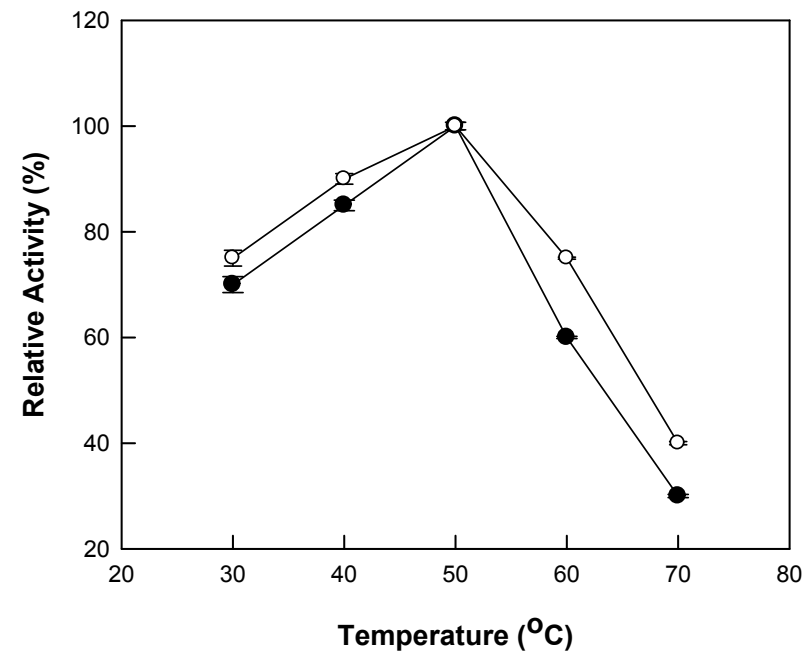

Fig. 1. Effects of $\mathrm{pH}(\mathrm{A})$ and temperature (B) on the cellulase and xylanase activities from $B$. subtilis NC1. (A) The reactions were performed in $50 \mathrm{mM}$ citrate buffer $(\mathbf{O}, \mathrm{pH}$ 3.0-6.0) or $50 \mathrm{mM}$ Phospahte buffer $(\bigcirc, \mathrm{pH} 6.0-8.0)$ or $50 \mathrm{mM}$ Tris buffer $(\boldsymbol{\square}, \mathrm{pH} 8.0-9.0)$ containing $1 \%$ substrate and $0.5 \mathrm{U} / \mathrm{ml}$ of enzyme at $50^{\circ} \mathrm{C}$ for $10 \mathrm{~min}$. (B) The reactions were performed in $50 \mathrm{mM}$ acetate buffer (pH 5.0) containing $1 \%$ substrate and $0.5 \mathrm{U} / \mathrm{ml}$ of enzyme at $50^{\circ} \mathrm{C}$ for $10 \mathrm{~min}$. The open symbols and closed symbols exhibit effect of $\mathrm{pH}$ and temperature on xyanase and cellulase activities, respectively. Data represent the means of three experiments and error bars represent standard deviation.

해서는 효소 활성이 전혀 확인되지 않았다. B. subtilis NC1 유래 효소액의 경우 cellulase에 대한 활성은 Endo-type cellulase (EC 3.2.1.4)의 전형적인 기질로 주로 이용되어지는 CM-cellulose에 가장 높은 효소 활성을 나타내었으며 Exo-type cellulase (EC 3.2.1.91)의 기질로 주로 이용되고 있는 Avicel에 대해서는 활성이 측정되지 않았다. 이러한 결과로부
Table 2. Substrate specificity of enzyme solution from B. subtilis NC1

\begin{tabular}{lc}
\hline Substrate & Specific activity $(\mathrm{U} / \mathrm{ml})$ \\
\hline CMC & $0.5 \pm 0.005$ \\
Beechwood xylan & $0.38 \pm 0.003$ \\
Birchwood xylan & $0.35 \pm 0.003$ \\
Avicel & N.D \\
\hline
\end{tabular}

${ }^{*}$ N.D.: not detected

Data represent the means of three experiments with standard deviation.

터 본 균주 유래의 cellulase는 endo-type cellulase (EC 3.2.1.4) 임이 강하게 시사되었다. 그리고, xylanase에 대한 활성은 endo-type xylanase의 전형적인 기질인 Beechwood xylan과 Birchwood xylan에 대하여 높은 활성을 나타내는 특징으로부 터 본 균주 유래의 xylanase는 endo-type xylanase (EC 3.2.1.8) 임이 강하게 시사되었다.

\section{효소 유전자의 cloning 및 sequencing}

B. subtilis $\mathrm{NC1}$ 유래 cellulase와 xylanase 유전자를 확보하

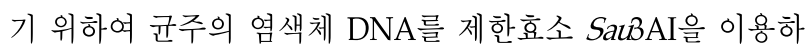
여 부분 절단을 시킨 후 회수한 DNA단편을 pHSG298에 ligation하여 제작한 발현 벡터로 E. coli $\mathrm{DH} 5 \mathrm{a}$ 를 형질전환시켰다. 형 질 전환체를 $1 \% \mathrm{CM}$-cellulose와 Beechwood xylan을 각각 기질로 이용하여 trypan blue를 첨가하여 제작한 Agar-LB 배 지에 도말 한 결과 효소 유전자가 cloning 된 발현벡터로 형질 전환 된 형질전환체의 주위에 명확한 활성환이 생성되는 것을 확인하였다(Fig. 2). E. coli DH5a에는 균체 내부에서 발현 된 효소를 균체 외부로 분비 할 수 있는 시스템이 거의 존재하지 않기 때문에 E. coli $\mathrm{DH} 5 a$ 에 의해 발현된 재조합 효소가 $E$. coli $\mathrm{DH} 5 \mathrm{a}$ 에 의해 분비되었다기 보다는 E. coli DH5a 일부가 배양중에 사멸기에 접어들면서 균체가 파괴되어 균체 내부에 발현되었던 재조합 효소가 밖으로 유출됨으로서 형성되는 활 성환으로 판단되어진다. 명확한 활성환을 보였던 형질전환체 로부터 plasmid를 추출하여 plasmid에 cloning되어있는 DNA 염기 배열을 분석한 결과 cellulase와 xylanase로 추정되 는 효소 유전자 배열이 각각 확인되었다. 먼저, cellulase에 대 한 유전자는 499 개 아미노산을 지정하는 $1,500 \mathrm{bp}$ 의 open Reding Frame (ORF)으로 구성되어져 있었으며, 아미노산 배 열로부터 추정되는 효소 분자량은 $55,251 \mathrm{Da}$ 이였다. 그리고, 아미노산 배열을 이용하여 효소의 상동성을 검토한 결과 본 연구에서 얻어진 cellulase의 아미노산 배열은 glycosyl hydrolase family $(\mathrm{GH})$ 5에 속하는 효소와 매우 높은 상동성을 나타 내는 것으로부터 본 유전자로부터 발현되는 cellulase는 GH5 에 속하는 효소임이 강하게 시사되었다 $[8,21,28]$. 본 연구에서 규명된 cellulase 유전자 배열 및 유전자 유래 아미노산 배열은 GenBank에 accession number AB695293으로 등록하였으며, 
(A)

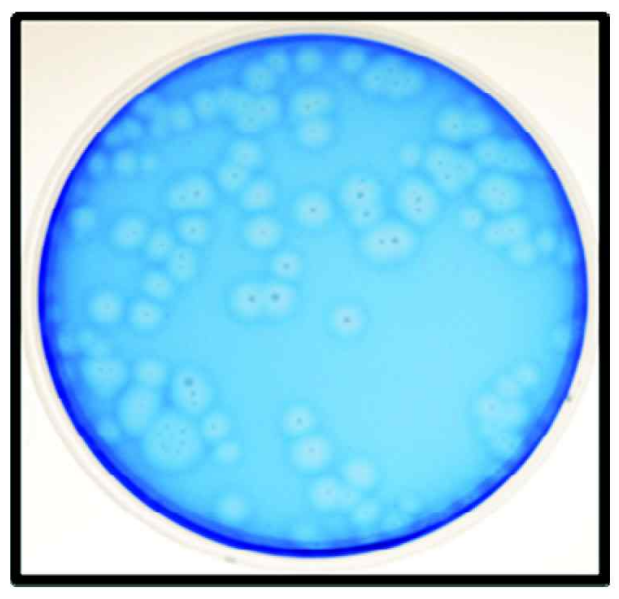

(B)

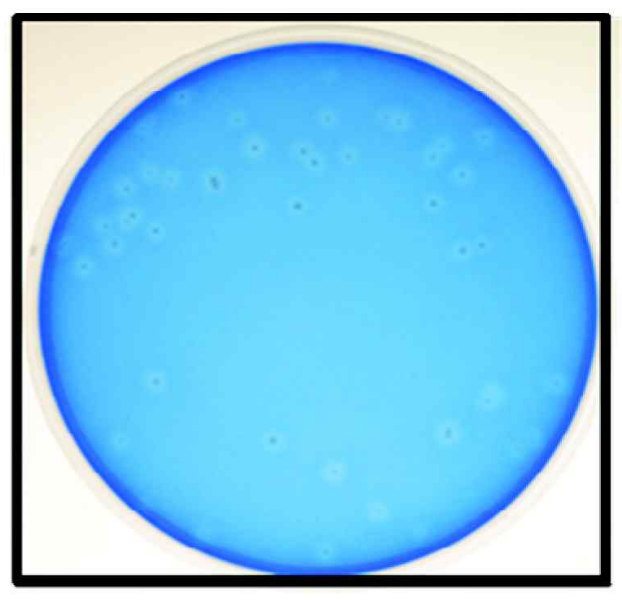

Fig. 2. Analysis of recombinant cellulase (A) and xylanase (B) activities on the Agar-LB plate containing trypan blue and CM-cellulose (A) and Beechwood xylan (B), respectively, as substrate. The clear zones around colonies were confirmed by recombinant enzyme expressed in E. coli DH5a harboring enzyme gene from B. subtilis $\mathrm{NC1}$.

PC CEI MKRSISIF I TCLLITLLTMGGMLASPASAAGTKTPUAKNGQLS IKGTQLUNRDGKAUQLKGISSHGLQWYGEYUNKDSLKWLRDDWGITU 9 GB CE1 MKRS ISIF I TCLL I TLLTMGGMIASPASAAGTKTPUAKNGQLSIKGTQLUNRDGKAUQLKG ISSHGLQWYGEYUNKDSLKWLRDDWG I TU 9 BS CEI MKRSISIFITCLL I TLLTHGG IMASPASAAGTKTPUAKNGQLS IKGTQLUNRDGKAUQLKG ISSHGLQWYGEYUNKDSLKWLRDDWG ITU 9 BS NC1 MKRSISIF I TCLL I TLLTHGGMI ASPASAAGTKTPUAKNGQLS IKGTQLUNRDGKAUQLKG ISSHGLQWYGEYUNKDSLKWLRDDWG I TU 9

PC CEI FRAAMYTADGGY IDNPSUKNKUKEAUEAAKELG I YUIIDWHILNDGNPNQNKEKAKEFFKEMSSLYGNTPNUIYEIANEPNGDUNWKRD I 18 G GB CE1 FRAAHYTADGGYIDNPSUKNKUKEAUEAAKELGIYUI IDUHILNDGNPNQNKEKAKEFFKEHSSL YGNTPNUIYE IANEPNGDUNUKRDI 18 BS CE1 FRAAMYTADGGYIDNPSUKNKUKEAUEAAKELGIYUIIDWH ILNDGNPNONKEKAKEFFKEMSSLYGNTPNUIYE IANEPNGDUNUKRDI 18B BS NC1 FRAAMYTADGYIDNPSUKNKUKEAUEAAKELG IYUI IDWHILNDGNPNQNKEKAKEFFKEMSSLYGNTPNUIYEIANEPNGDUNWKRD I 180 *****************************************************************************************************

PC CEI KPYAEEUISUIRKNDPDNI I IUGTGTWSQDUNDAADDQLKDANUMYALHFYAGTHGQFLRDKANYALSKGAPIFUTEWGTSDASGNGGUF 27 GB CE1 KPYAEEUISUIRKNDPDNIIIUGTGTUSQDUNDAADDQLKDANUMYALHFYAGTHGQFLRDKANYALSKGAP IFUTEUGTSDASGNGGUF 270 BS CE1 KPYAEEUISUIRKNDPDNIIIUGTGTWSQDUNDAADDQLKDANUNYALHFYAGTHGQFLRDKANYALSKGAPIFUTEWGTSDASGNGGUF 270 BS NC1 KPYAEEUISUIRKNDPDNI I IUGTGTWSQDUNDAADDQLKDANUHYALHFYAGTHGQFLRDKANYALSKGAPIFUTEWGTSDASGNGGUF 27G ***************************************************************************************************

PC CE1 LDQSREWLKYLDSKTISWUNWNLSDKQESSSALKPGASKTGGWOLSDLSASGTFURENILGTKDSTKDIPETPAKDKPTRENGISUQYRA 36 GB CE1 LDQSREWLKYLDSKT ISWUNWNLSDKQESSSALKPGASKTGGWRLSDLSASGTFURENILGTKDSTKDIPETPSKDKPTQENG ISUQYRA 36 BS CE1 LDQSREWLKYLDSKTISWUNWNLSDKQESSSALKPGASKTGGWRLSDLSASGTFURENILGTKDSTKDIPETPAKDKPTQENG ISUQYRA 360 BS NC1 LDQSREWLKYLDSKTISWUNWNLSDKQESSSALKPGASKTGGWRLSDLSASGTFURENILGTKDATKDIRETPAKDKPTQENG ISUQYRA 36 *******************************************;*************************************************)

PC CE1 GDGSMNSNQIRPQLQIKNNGNTTUDLKDUTARYWYKAKNKGQNUDCDYAQIGCGNUTYKFUTLHKPKQGADTYLELGFKNGTLAPGASTG 450 GB CE1 GDGSHNSNQIRPQLQIKNNGNTTUDLKDUTARYUYKAKNKGONFDCDYAQIGCGNUTHKFUTLHKPKQGADTYLELGFKNGTLAPGASTG 450 BS CE1 GDGSHNSNQIRPQLQIKNNGNTTUDLKDUTARYWYKAKNKGQNUDCDYAQIGCGNUTHKFUTLHKPKQGADTYLELGFKNGTLAPGASTG 45B BS NC1 GDGSHNSNQIRPQLQIKNNGNT TUDLKDUTARYWYKAKNKGQNUDCDYAQIGCGNUTHKFUTLHKPKQGADTYLELGFKNGTLGPGASTG 450 ***********************************************************************************.*******

PC CEI NIQLRLHNDDWSNYAQSGDYSFFKSNTFKTTKKITLYD----------- 488

GB CE1 NIQLRLHNDDWSNYAOSGDYSFFKSNTFKTTKKI TLYDQRKLIWGAEPN 499

BS CE1 NIQLRLHNDDWSNYAQSGDYSFFKSNTFKTTKKITLYDQGKLIWGTEPN 499

BS NC1 NIQLRLHNDDWSNYAQSGDYSFFKSNTFKTTKKITLYDQGKLIWGTEPN 499

****************************************01

Fig. 3. Alignment of amino acid sequences of GH5 cellulases. PC CEl, cellulase from Paenibacillus campinasensis (ADI39639); GB CEl, cellulase from Geobacillus stearothermophilus (AD021451); BS CEl, cellulase from B. subtilis (AE000512), and BS NC1, cellulase from $B$. subtilis $\mathrm{NC1}$ (AB695293). The amino acids highly conserved among GH5 cellulase are showed with asterisk.

본 연구에 의해 단리된 cellulase과 높은 상동성을 보인 $\mathrm{GH} 5$ 에 속하는 cellulase의 아미노산 배열에 대한 alignment를 Fig. 3 에 나타내었다. 그리고, xylanase의 경우에는 422 아미노산을 지정하는 $1,269 \mathrm{bp}$ 의 $\mathrm{ORF}$ 로 구성되어지는 유전자로서, xyla- nase 유전자로부터 얻어진 아미노산 배열을 이용하여 추정한 효소 분자량은 약 $47,423 \mathrm{Da}$ 이였다. Xylanase 아미노산 배열 을 이용하여 상동성을 검토한 결과 본 연구에서 얻어진 xylanase의 아미노산 배열은 $\mathrm{GH} 30$ 에 속하는 효소들과 높은 상동 
BAM $X y 1$ MMSGUKKPICLLLACFTHLSULLMGPGAAEULAASDUTUNUSAEKQUIRGFGGMNHPAWUGDLTAAQRETAFGNGQNQLGFSILRIHUDE 99 BAT XY1 MHSCUKKPICLLLUCFTHLSUHLAGPGATEULAASDUTUNLSAEKQUIRGFGGMNHPAWIGDLTAAQRETAFGNGQNQLGFSILRIHIDE 9 BST Xy1 MIPRIKKTICULLUCFTMLSUHLG-PGATEULAASDUTUNUSAEKQUIRGFGGMNPAWAGDLTAAQRETAFGNGQNQLGFSILRIHUDE 89

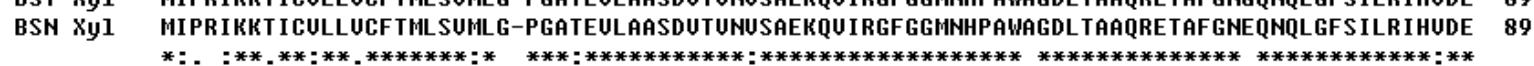

BAM XY1 NRNNWYKEUETAKSAIKHGAIUFASPUNPPNDMUETFNHNGDTSAKRLRYDKYAAYAQHLNDFUTFMKNNGUNLYAISMQNEPDYAHEWT 180 BAT XY1 NRNNWYREUETAKSAIKHGAIUFASPWNPPSNMUETFNHNGDASAKRLRYDKYAAYAQHLNDFUTYMKNNGUNLYAISUQNEPDYAHEWT 18 BST XY1 NRNNWYKEUETAKSAUKHGAIUFASPWNPPSDHUETFNRNGDTSAKRLKYNKYAAYAQHLNDFUTFHKNNGUNL YAISUQNEPDYAHEWT 179 BSN XY1 NRNNWYKEUETAKSAUKHGAIUFASPWNPPSDHUETFNRNGDTSAKRLKYDKYAAYAQHLNDFUTFHKNNGUNLYAISUQNEPDYAHEWT 179 ******:********:**************.,:******;***;*****;*;**************;************:***********

BAH XY1 WWTPQEILRFHRENASSINARUIAPESFQYLKNISDPILNDPQALRNHDILGTHLYGTQUSQFPYPLFKQKGAGKDLWHTEUYYPNSDNN 27 G BAT $X y 1$ WWTPQEILRFMRENAGSINARUIAPESFQYLKNISDPILNDPQALRNMDILGTHLYGTQUSQFPYPLFKQKGAGKELWHTEUYYPNSDNN 27 BST $\mathrm{Xy1}$ WWTPQEILRFMRENAGSINARUIAPESFQYLKNLSDPILNDPQALANMDILGTHLYGTQUSQFPYPLFKQKGAGKDLWHTEUYYPNSDTN 269 BSN XY1 WWTPQEILRFMRENAGSINARUIAPESFQYLKNLSDPILNDPQALANINDILGTHLYGTQUSQFPYPLFKQKGAGKDLWMTEUYYPNSDNN 269

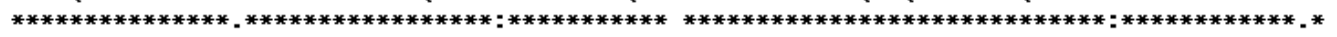

BAM XY1 SADRWPEALDUSQH IHNSHTEGDFQAYUWWY IRRSYGPHKEDGT ISKRGYNHAHFSKFURPGYURIDATKNPNPNUYUSAYKGDNKUUIU 360 BAT XY1 SADRWPEALGUSEH IHHSHUEGDFQTYUWWYIRRSYGPHKEDGK I SKRGYNHAHFSKFURPGYIRUDATKNPNANUYUSAYKGDNKUUIU 36 BST XY1 SADRWPEALDUSQHI HNAHUEGDFQAYUWWYIRRSYGPHKEDGT ISKRGYNHAHFSKFURPGYUR IDATKNPNANUYUSAYKGDNKUUIU 359 BSN XY1 SADRWPEALDUSQHIHNAMUEGDFQAYUWWYIRRSYGPMKEDGTISKRGYNMAHFSKFURPGYUR IDATKNPNANUYUSAYKGDNKUUIU 359

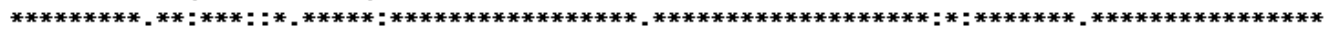

BAM XY1 AINKTNTGUNQNFULQNGSASQUSRWUTSSSSNLQPGTDLNUTDNHFWAHLPAQSUTTFUUKR 423

BAT XY1 AINKSNTGUNQNFULQNGSASQUSRWITSGSSNLQPGTNLNUTDNHFWAHLPAQSUTTFUUKR 423

BST XY1 AINKSNTGUNQNFULQNGSASNUSRWITSSSSNLQPGTNLTUSGNHFWAHLPAQSUTTFUUNR 422

BSN XY1 AINKSNTGUNQNFULQNGSASNUSRWI TSSSSNLQPGTNL TUSGNHFWAHLPAQSUTTFUUNR 422

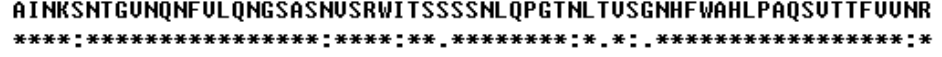

Fig. 4. Alignment of amino acid sequences of GH30 xylanases. BAM Xyl, xylanase from B. amyloliquefaciens (YP_003920505); BAT Xyl, xylanase from B. atrophaeus (YP_003973306); BST Xyl, xylanase from B. subtilis (NP_389697), and BSN Xyl, xylanase from B. subtilis NC1 (AB695294). The amino acids highly conserved among GH30 xylanases are showed with asterisk.

성을 나타내었으므로 $\mathrm{GH}$ 30에 속하는 xylanase임이 강하게 시사되었다[2,18]. 본 연구에서 규명한 xylanase 유전자 및 유 전자 유래 아미노산 배열은 GenBank에 accession number $\mathrm{AB} 695294$ 로 등록하였으며, 본 연구에서 단리한 xylanase와 높 은 상동성을 보인 $\mathrm{GH} 30$ 에 속하는 xylanase와의 아미노산 배 열의 alignment를 Fig. 4에 나타내었다. 본 연구에 의하여 본 연구에서는 trypan blue를 이용하여 CM-cellulose와 Beechwood xylan을 염색한 agar 배지를 제작함으로서 환경 시료로부터 cellulase와 xylanase를 생산하는 균주를 용이하게 단리하였으며, 효소 유전자 cloning에도 적용하여 본 균주 유 래의 cellulase와 xylanase 유전자를 보유한 형질전환체를 용 이하게 선별함으로서 cellulase와 xylanase 효소 유전자 2 종류 를 규명하였다.

\section{감사의 글}

본 연구는 농림수산식품부 생명산업기술개발사업(농수축 산용 미생물제재 산업화 모델 시스템 구축 및 제품 개발)의 지원으로 이루어졌으며, 이에 감사드립니다.

\section{References}

1. Beguin, P. and Aubert, J. 1994. The biological degradation of cellulose. FEMS Microbiol. Rev. 13, 25-58.
2. Cai, S., Li, J., Hu, F., Zhang, K., Luo, Y., Janto, B., Boissy, R., Ehrlich, G. and Dong, Y. 2010. Cellulosilyticum ruminicola, a newly described rumen bacterium that possesses redundant fibrolytic-protein-encoding genes and degrades lignocellulose with multiple carbohydrate- borne fibrolytic enzymes. Appl. Environ. Microbiol. 76, 3818-3824.

3. Cuyvers, S., Dornez, E., Moers, K., Pollet, A., Delcour, J. and Courtin, C. 2011. Evaluation of the xylan breakdown potential of eight mesophilic endoxylanases. Enzyme Microb. Technol. 49, 305-311.

4. de Almeida, M. N., Guimarães, V. M., Bischoff, K. M., Falkoski, D. L., Pereira, O. L., Gonçalves, D. S. and de Rezende, S. T. 2011. Cellulases and hemicellulases from endophytic Acremonium species and its application on sugarcane bagasse hydrolysis. Appl. Biochem Biotechnol. 165, 594-610.

5. Díaz, I., Donoso-Bravo, A. and Fdz-Polanco, M. 2011. Effect of microaerobic conditions on the degradation kinetics of cellulose. Bioresour Technol. 102, 10139-10142.

6. Hideno, A., Inoue, H., Tsukahara, K., Yano, S., Fang, X., Endo, T. and Sawayama, S. 2010. Production and characterization of cellulases and hemicellulases by Acremonium cellulolyticus using rice straw subjected to various pretreatments as the carbon source. Enzyme Microb. Technol. 48, 162-168.

7. Hu, J., Arantes, V. and Saddler, J. N. 2011. The enhancement of enzymatic hydrolysis of lignocellulosic substrates by the addition of accessory enzymes such as xylanase: is it an additive or synergistic effect. Biotechnol. Biofuels. 4, 36. 
8. Jung, K. H., Chun, Y. C., Lee, J. C., Kim, J. H. and Yoon, K. H. 1996. Cloning and expression of a Bacillus sp. 79-23 cellulase gene. Biotechnol. Lett. 18, 1077-1082.

9. Kanna, M., Yano, S., Inoue, H., Fujii, T. and Sawayama, S. 2011. Enhancement of $\beta$-xylosidase productivity in cellulase producing fungus Acremonium cellulolyticus. AMB Express. $1,15$.

10. Kataria, R. and Ghosh, S. 2011. Saccharification of Kans grass using enzyme mixture from Trichoderma reesei for bioethanol production. Bioresour. Technol. 102, 9970-9975.

11. Ma, X. D., Ke, T., Xiong, L., Yan, H. and Ma, L. X. 2007. A new plate method for screening of polysaccharide-degrading enzymes and their producing microorganisms. Wei Sheng Wu Xue Bao. 47, 1102-1104.

12. Metz, B., Seidl-Seiboth, V., Haarmann, T., Kopchinskiy, A., Lorenz, P., Seiboth, B. and Kubicek, C. P. 2011. Expression of biomass-degrading enzymes is a major event during conidium development in Trichoderma reesei. Eukaryot Cell 10, 1527-1535.

13. Miller, G. L. 1959. Use of dinitrosalicylic acid reagent for determination of reducing. Anal. Chem 31, 426-428.

14. Peng, L. and Gutterson, N. 2011. Energy crop and biotechnology for biofuel production. J. Intergr. Plant Biol. 53, 253-256.

15. Tomme, P., Warren, R. A. and Gilkes, N. R. 1995. Cellulose hydrolysis by bacteria a fungi. Adv. Microbial. Physiol. 37, 1-81.

16. Sambrook, J., Brent, R. and Kingston, T. 1987. Current protocols in molecular biology. Greene Publishing Associates and Wiley-Interscience, New York.

17. Silva, G. G., Couturier, M., Berrin, J. G., Buléon, A. and Rouau, X. 2012. Effects of grinding processes on enzymatic degradation of wheat straw. Bioresour Technol. 103, 192-200.

18. Suzuki, T., Ibata, K., Hatsu, M., Takamizawa, K. and Kawai, K. 1997. Cloning and expression of a 58-kDa xylanase VI gene (xynD) of Aeromonas caviae ME-1 in Escherichia coli which is not categorized as a family $\mathrm{F}$ or family $\mathrm{G}$ xylanase. J. Ferment. Bioeng. 84, 86-89.

19. Várnai, A., Huikko, L., Pere, J., Siika-Aho, M. and Viikari, L. 2011. Synergistic action of xylanase and mannanase improves the total hydrolysis of softwood. Bioresaur Technol. 102, 9096-9104

20. Xie, G. and Peng, L. 2011. Genetic engineering of energy crops: a strategy for biofuel production in China. J. Intergr. Plant Biol. 53, 143-150.

21. Yang, D., Weng, H., Wang, M., Xu, W., Li, Y. and Yang, H. 2010. Cloning and expression of a novel thermostable cellulase from newly isolated Bacillus subtilis strain I15. Mol. Biol. Rep. 37, 1923-1929.

22. Yu, L., Z. Chen, X., Tong, X., Li, K. and Li, W. W. 2012. Anaerobic degradation of microcrystalline cellulose: Kinetics and micro-scale structure evolution. Chemosphere 86, 348-353.

23. Zhang, Y., Han, B. and Ezeji, T. C. 2012. Biotransformation of furfural and 5-hydroxymethyl furfural (HMF) by Clostridium acetobutylicum ATCC 824 during butanol fermentation. N. Biotechnol. 29, 345-351.

24. Zhang, J., Tuomainen, P., Siika-Aho, M. and Viikari, L. 2011. Comparison of the synergistic action of two thermostable xylanases from GH families 10 and 11 with thermostable cellulases in lignocellulose hydrolysis. Bioresour Technd. 102, 9090-9095.

25. Zhou, C. H., Xia, X., Lin, C. X., Tong, D. S. and Beltramini, J. 2011. Catalytic conversion of lignocellulosic biomass to fine chemicals and fuels. Chem Soc. Rev. 40, 5588-5617.

26. Zhou, J., Bao, L., Chang, L., Liu, Z., You, C. and Lu, H. 2012. Beta-xylosidase activity of a GH3 glucosidase/xylosidase from yak rumen metagenome promotes the enzymatic degradation of hemicellulosic xylans. Lett. Appl. Microbiol. 54, 79-87.

27. Zhou, J., Bao, L., Chang, L., Zhou, Y. and Lu, H. 2012. Biochemical and kinetic characterization of GH43 $\beta-D$ : -xylosidase/a-L: -arabinofuranosidase and GH30 a-L: -arabinofuranosidase/ $\beta-\mathrm{D}$ : -xylosidase from rumen metagenome. J. Ind Microbiol. Biotechnol. 39, 143-152.

28. Zvidzai, C. J., Hatti-Kaul, R., Sithole-Niang, I., Zvauya, R. and Delgado, O. 2002. Cloning, sequencing and expression of an endo-b-1,4-glucanase (celG) gene of a Bacillus subtilis CHZ1. J. Appl. Sci. South Afr. 8, 65-75. 
초록 : Bacillus subtilis NC1 유래 cellulase와 xylanase의 특성 규명 및 효소 유전자의 규명

박창수 ${ }^{1} \cdot$ 강대욱 $^{2}$ 최낙식 ${ }^{3}$ *

( ${ }^{1}$ 대구가톨릭대학교 식품가공학전공, ${ }^{2}$ 창원대학교 보건의학과, ${ }^{3}$ 우리생명과학(주)

Carboxymethylcellulose (CM-cellulose)와 Beechwood xylan을 각각 기질로 사용하여 trypan blue를 첨가하여 제작한 Agar-LB 배지 상에서 명확한 활성환을 형성하는 균주를 cellulase와 xylanase 생산 균주로 단리하였다. 단리한 균주 유래의 $16 \mathrm{~S}$ rRNA 유전자 및 API $50 \mathrm{kit}$ 를 분석한 결과 Bacillus subtilis와 약 $99.5 \%$ 의 높은 상동성을 보였기에 본 균주를 Bacillus subtilis로 동정하여 B. subtilis NC1로 명명하였다. B. subtilis NC1 유래 cellulase와 xylanase는 CM-cellulose와 Beechwood xylan에 대하여 각각 높은 효소 활성을 보였으며, 두 효소 모두 pH 5.0과 $50^{\circ} \mathrm{C}$ 의 조건하에서 가장 높은 효소 활성을 보였다. B. subtilis $\mathrm{NC1}$ 균주 유래 cellulase와 xylanase 유전자를 cloning하기 위하여 shot-gun cloning 방법을 이용하여 B. subtilis NC1 염색체 DNA로부터 효소 유전자를 cloning하 여 유전자 배열을 규명한 결과 cellulase 유전자는 아미노산 499 개를 암호화하는 $1,500 \mathrm{bp}$ 의 open reading frame (ORF)으로 이루어져 있었으며, 아미노산 배열로부터 추정되는 분자량은 $55,251 \mathrm{Da}$ 이었다. 그리고, xylanase에 대한 유전자는 아미노산 422 개를 암호화하는 $1,269 \mathrm{bp}$ 의 ORF로 이루어져 있었으며 유전자 유래 아미노산 배열 로부터 추정되는 단백질 분자량은 $47,423 \mathrm{Da}$ 이었다. 두 효소의 아미노산 배열을 이용하여 상동성을 검토한 결과 cellulase는 glycoside hydrolase family $(\mathrm{GH}) 5$ 에 속하는 cellulase와 xylanase는 GH30에 속하는 xylanase와 높은 상동성을 나타내었다. 